\title{
Arylisoquinoline-derived organoboron dyes with a triaryl skeleton show dual fluorescence
}

\author{
Vânia F. Pais ${ }^{1}$, Tristan Neumann ${ }^{1}$, Ignacio Vayá ${ }^{2}$, M. Consuelo Jiménez ${ }^{2}$, Abel Ros ${ }^{*} 3,4$ \\ and Uwe Pischel ${ }^{*}$
}

\section{Full Research Paper}

\section{Address:}

${ }^{1}$ CIQSO - Centre for Research in Sustainable Chemistry and Department of Chemistry, University of Huelva, Campus de El Carmen s/n, 21071 Huelva, Spain, ${ }^{2}$ Department of Chemistry/Institute of Chemical Technology UPV-CSIC, Universitat Politècnica de València, Camino de Vera s/n, 46022 Valencia, Spain, ${ }^{3}$ Institute for Chemical Research (CSIC-US) and Innovation Center in Advanced Chemistry (ORFEO-CINQA), C/ Américo Vespucio 49, 41092 Seville, Spain and ${ }^{4}$ Department of Organic Chemistry, University of Seville, C/ Prof. García González 1, 41012 Seville, Spain

Email:

Abel Ros* - abel.ros@iiq.csic.es; Uwe Pischel* uwe.pischel@diq.uhu.es

* Corresponding author

Keywords:

anions; dyes; fluorescence; laser-flash photolysis; organoboron
Beilstein J. Org. Chem. 2019, 15, 2612-2622.

doi:10.3762/bjoc. 15.254

Received: 05 July 2019

Accepted: 14 October 2019

Published: 04 November 2019

This article is part of the thematic issue "Dyes in modern organic chemistry".

Guest Editor: H. Ihmels

(C) 2019 Pais et al.; licensee Beilstein-Institut.

License and terms: see end of document.

\begin{abstract}
Four new dyes that derive from borylated arylisoquinolines were prepared, containing a third aryl residue (naphthyl, 4-methoxynaphthyl, pyrenyl or anthryl) that is linked via an additional stereogenic axis. The triaryl cores were synthesized by Suzuki couplings and then transformed into boronic acid esters by employing an $\operatorname{Ir}(\mathrm{I})$-catalyzed reaction. The chromophores show dual emission behavior, where the long-wavelength emission band can reach maxima close to $600 \mathrm{~nm}$ in polar solvents. The fluorescence quantum yields of the dyes are generally in the range of $0.2-0.4$, reaching in some cases values as high as $0.5-0.6$. Laserflash photolysis provided evidence for the existence of excited triplet states. The dyes form fluoroboronate complexes with fluoride anions, leading to the observation of the quenching of the long-wavelength emission band and ratiometric response by the build-up of a hypsochromically shifted emission signal.
\end{abstract}

\section{Introduction}

Boron-containing tri- and tetra-coordinated chromophores have attracted considerable interest due to their often peculiar and highly advantageous photophysical properties that include spec- trally tunable and highly intense fluorescence $[1,2]$. On the one hand, those compounds that contain the boron atom in a valence-saturated situation corresponding to $\mathrm{sp}^{3}$ hybridization 
(such as Bodipy dyes [3,4], N,C-chelate organoboron dyes [5-9], BASHY dyes [10,11] or Boranils [12,13]) often feature quite rigid structures which contribute to high fluorescence quantum yields. These dyes have been applied for example in optoelectronics [14-16], sensing [17-20], and bioimaging [6,2026]. On the other hand, boron with $\mathrm{sp}^{2}$ hybridization, such as in triarylboranes, offers the possibility to modulate fluorescence properties by the addition of Lewis bases (e.g., fluoride ions [27-31]) or by exploring the electron-accepting properties of the boron, including charge-transfer and photoinduced electrontransfer phenomena or two-photon absorption [32-36].

As part of our research program we have developed arylisoquinolines that integrate a boronic acid ester [37-39] or a $\mathrm{BMes}_{2}$ unit $[6,40]$. The presence of the boron-substituent confers interesting photophysical properties to these dyes such as intramolecular charge-transfer processes and tunable redshifted emission bands. Generally, the so far investigated borylated arylisoquinoline dyes show principally fluorescence quenching (on-off switching) on the formation of the corresponding fluoroboronate complexes [37].

Herein, we extended our previously reported arylisoquinolinederived organoboron dye platform with an additional axially linked aryl residue (see structures 16-19 in Figure 1) in the expectation to modulate the fluorescence properties and fluoride response of these dyes. The additional aryl residues allow the verification of the effect of aromatic conjugation (naphthyl, anthryl, pyrenyl) and electron-donor strength (naphthyl versus 4-methoxynaphthyl) on the photophysical properties. Beside the observation of interesting dual emission properties for these dyes, some showed a pronounced ratiometric fluorescence response on fluoride ion addition.

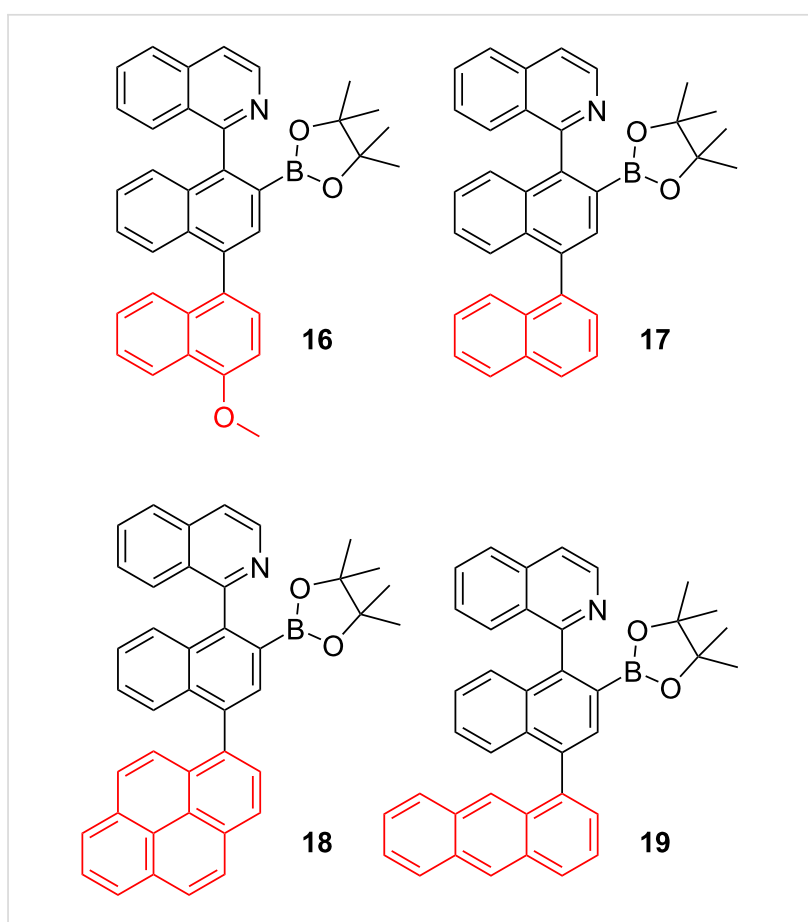

Figure 1: Structures of the dyes 16-19.

\section{Results and Discussion Synthesis of the borylated dyes 16-19}

For the synthesis of the triaryl systems 12-15, precursors of the organoboron dyes 16-19, the construction of two stereogenic axes was required. Therefore, a synthetic route based on consecutive cross-coupling reactions was planned. Starting from 1-bromo-4-methoxynaphthalene (1), the Pd-catalyzed Suzuki coupling reaction with commercial boronic acids afforded the naphthyl and pyrenyl derived methyl ethers $\mathbf{2}$ and $\mathbf{3}$ in $78 \%$ and $87 \%$ yield, respectively (Scheme 1 ). For the synthe-<smiles>COc1ccc(Br)c2ccccc12</smiles><smiles>Clc1cccc2cc3ccccc3cc12</smiles>

1) $\mathrm{B}_{2} \operatorname{pin}_{2}$ (1.0 equiv), KOAc (1.7 equiv) $\mathrm{Pd}_{2} \mathrm{dba}_{3}(1 \mathrm{~mol} \%)$, SPhos $(8 \mathrm{~mol} \%)$ 1,4-dioxane, $110^{\circ} \mathrm{C}$

2) 1 (0.9 equiv), $\mathrm{K}_{3} \mathrm{PO}_{4}(5 \mathrm{M})$, $110^{\circ} \mathrm{C}$<smiles>COc1ccc(Br)c2ccccc12</smiles>

2, 78\%, Ar = 1-naphthyl 3, $87 \%, \mathrm{Ar}=1$-pyrenyl
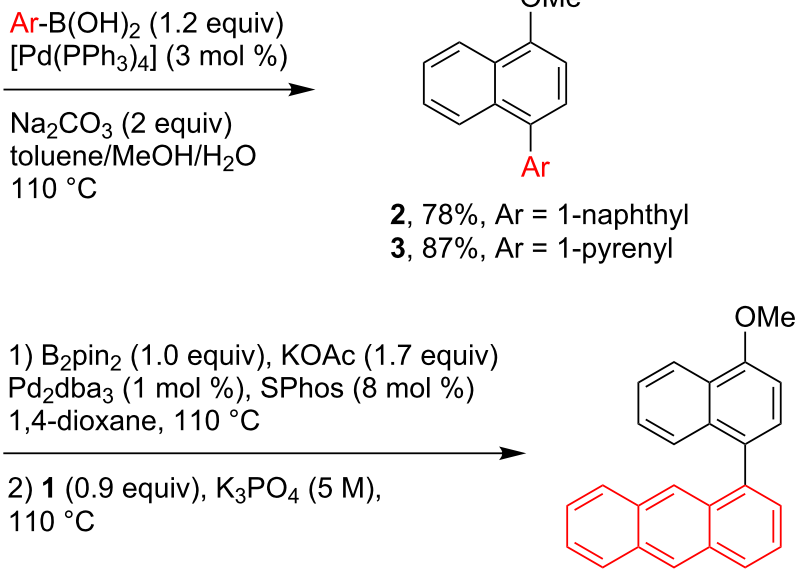

5, $82 \%$ 
sis of the anthryl derivative $\mathbf{5}$ a Pd-catalyzed one-pot reaction consisting of a borylation and Suzuki coupling was applied. Thus, starting from 1-chloroanthracene (4) and using SPhos/ $\mathrm{Pd}_{2} \mathrm{dba}_{3}(8: 1)$ as the catalyst, a full conversion to the Miyauratype borylated intermediate was achieved (TLC analysis) after 5 hours at $110^{\circ} \mathrm{C}$. The addition of 1-bromo-4-methoxynaphthalene (1, 0.9 equiv) and $\mathrm{K}_{3} \mathrm{PO}_{4}$, and stirring overnight at $110{ }^{\circ} \mathrm{C}$, afforded the biaryl methyl ether 5 in an $82 \%$ yield (Scheme 1). Similarly, Buchwald's methodology [41] was applied in the synthesis of 7, which was obtained in $70 \%$ yield after tetrahydropyran (THP) group deprotection in $\mathrm{MeOH} / \mathrm{CH}_{2} \mathrm{Cl}_{2}$ using $\mathrm{TsOH} \cdot \mathrm{H}_{2} \mathrm{O}$ as the catalyst (Scheme 2 ). In a conventional triflation $\left(\mathrm{Tf}_{2} \mathrm{O}\right.$, DMAP cat.), 7 was converted into 8 with a yield of $86 \%$. For the synthesis the triflates 9-11 a one-pot demethylation-triflation sequence was followed (Scheme 2). The treatment of biaryl methyl ethers $\mathbf{2}, \mathbf{3}$ or $\mathbf{5}$ with $\mathrm{BBr}_{3}$ (1.1 equiv) in anhydrous $\mathrm{CH}_{2} \mathrm{Cl}_{2}\left(0^{\circ} \mathrm{C} \rightarrow \mathrm{rt}\right)$ allowed the transformation into the alcohol intermediates, which were treated with triflic anhydride $\left(\mathrm{Tf}_{2} \mathrm{O}\right)$ in dry dichloromethane to afford $\mathbf{9 - 1 1}$ in $59-79 \%$ yield.

With the triflates 8-11 at hand, these were transformed into the triaryl systems 12-15 following a similar Pd-catalyzed one-pot borylation-Suzuki coupling strategy as mentioned above, using 1-chloroisoquinoline as the coupling partner (Scheme 3). The desired compounds $\mathbf{1 2 - 1 5}$ were obtained in $44-70 \%$ yield. The ${ }^{1} \mathrm{H}$ NMR spectra, recorded at $25{ }^{\circ} \mathrm{C}$, showed the coexistence of the syn and anti atropisomers because of the slow rotation around the chiral axis at this temperature. Free rotation around the $\mathrm{C}-\mathrm{C}$ bond was observed at $80{ }^{\circ} \mathrm{C}$ and hence, variable-temperature ${ }^{1} \mathrm{H}$ NMR studies showed coalescence of the signals to give an average spectrum (see Supporting Information File 1).

The synthesis of the borylated dyes 16-19 was carried out following a methodology that was previously reported by some of us [42] and that is based on the Ir-catalyzed nitrogen-directed ortho-borylation of arylisoquinolines [37,38]. Despite of the presence of many aromatic $\mathrm{C}-\mathrm{H}$ bonds which could be borylated, the choice of a suitable pyridine-hydrazone ligand [42] allowed to perform the borylation reactions at $55{ }^{\circ} \mathrm{C}$, showing complete regioselectivity in the $\mathrm{C}-\mathrm{H}$ borylation. This procedure afforded the dyes 16-19 in good to very good yields of $51-83 \%$ (Scheme 3 ). The introduction of the Bpin moiety hinders the free rotation around axis A (Scheme 3) of the compounds 16-19; therefore, complex mixtures of the syn/anti atropoisomers $(0.45: 0.55$; syn:anti) were observed in NMR spectroscopy. To facilitate the $\mathrm{C}-\mathrm{C}$ bond rotation around axis $\mathrm{B}$ (Scheme 3) and simplify the NMR spectra, the measurements were undertaken at $80{ }^{\circ} \mathrm{C}$ in $\mathrm{C}_{6} \mathrm{D}_{6}$ using a screw-cap NMR tube. Although significant changes were registered, a complete coalescence of the signals was not observed. The chiral HPLC analysis (see HPLC traces in Supporting Information File 1) demonstrated the high purity of compounds 16-19. The sharp peaks and separation times higher than 2 minutes are in accordance with a high rotation barrier. All compounds were identified by their ${ }^{1} \mathrm{H}$ and ${ }^{13} \mathrm{C}$ NMR spectra. The $\mathrm{sp}^{2}$ character of the boron was confirmed by ${ }^{11} \mathrm{~B}$ NMR spectroscopy, revealing a typical resonance signal at 31-32 ppm [43]. Hence, the iso-<smiles>COc1ccc(Br)c2ccccc12</smiles>

1) $B_{2} \operatorname{pin}_{2}$ (1.0 equiv), KOAC (1.7 equiv), $\mathrm{Pd}_{2} \mathrm{dba}_{3}(1 \mathrm{~mol} \%)$, SPhos $(8 \mathrm{~mol} \%)$ 1,4-dioxane, $110{ }^{\circ} \mathrm{C}$<smiles>O=[W]OCc1ccc(Br)c2ccccc12</smiles>
$6 \mathrm{Br}$ $\mathrm{K}_{3} \mathrm{PO}_{4}(5 \mathrm{M}), 110{ }^{\circ} \mathrm{C}$

3) $\mathrm{TsOH} \cdot \mathrm{H}_{2} \mathrm{O}$ $\mathrm{MeOH}: \mathrm{CH}_{2} \mathrm{Cl}_{2}$ 10:1
1) $\mathrm{BBr}_{3}$ (1.1 equiv), $\mathrm{CH}_{2} \mathrm{Cl}_{2}$ $0{ }^{\circ} \mathrm{C}$ to rt

2) $\mathrm{Tf}_{2} \mathrm{O}$ (1.2 equiv), $\mathrm{CH}_{2} \mathrm{Cl}_{2}$ DMAP (cat.), it<smiles>CCCOc1cccc2c(-c3ccc(OC)c4ccccc34)ccc(OC)c12</smiles>

$8,86 \%$

9,79\%, Ar = 1-naphthyl

10, 72\%, Ar = 1-pyrenyl $11,59 \%, A r=1$-anthryl 
<smiles>Brc1ccc(Br)c2ccccc12</smiles>

1) $B_{2} \operatorname{pin}_{2}$ (1.0 equiv), KOAc (1.7 equiv) $\mathrm{Pd}_{2} \mathrm{dba}_{3}(1 \mathrm{~mol} \%)$, SPhos (8 $\left.\mathrm{mol} \%\right)$ 1,4-dioxane, $110^{\circ} \mathrm{C}$

2)<smiles>Clc1cccc2ccccc12</smiles>
(0.83 equiv)

$\mathrm{K}_{3} \mathrm{PO}_{4}(5 \mathrm{M}), 110^{\circ} \mathrm{C}$

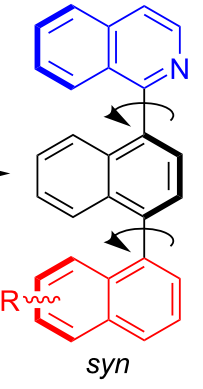<smiles>[R19]c1cccc2cccc(CCc3nccc4ccccc34)c12</smiles>

ca. $1: 1$ atropisomeric mixture

$12,44 \%, A r=4-m e t h o x y-1-$ naphthyl

13, $68 \%, A r=1$-naphthyl

$14,70 \%$, Ar $=1$-pyrenyl

$15,60 \%, A r=1$-anthryl

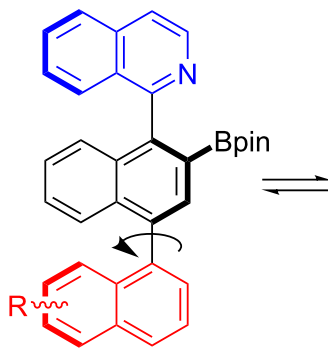

syn<smiles>[R15]c1cc(Cc2ccccc2)c(-c2nccc3ccccc23)c2ccccc12</smiles>

anti

$\mathrm{THF}, 55^{\circ} \mathrm{C}$

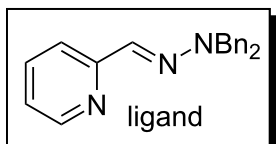

16, 62\%, Ar $=4$-methoxy-1-naphthyl

$17,83 \%, \mathrm{Ar}=1$-naphthyl

18, 51\%, Ar = 1-pyrenyl

19, $72 \%, A r=1$-anthryl

Scheme 3: Synthesis of 12-15 and the organoboron dyes 16-19.

quinoline nitrogen does not engage in the formation of an intramolecular Lewis pair, akin to related borylated arylisoquinolines $[37,38]$.

\section{UV-vis absorption and fluorescence properties}

The absorption and fluorescence properties of the herein investigated dyes 16-19 in air-equilibrated solutions, using three solvents (dichloromethane, acetonitrile, dimethyl sulfoxide), are summarized in Table 1. A first inspection of these data showed that the UV-vis absorption spectra feature the typical bands corresponding to their aromatic moieties (see Figure 2 for the spectra in acetonitrile). For example, for the dyes $\mathbf{1 8}$ and $\mathbf{1 9}$ $\pi-\pi^{*}$ transition bands in the wavelength range of $330-400 \mathrm{~nm}$ with characteristic vibronic fine structure were observed. Further, the dyes have a sharp peak at $322 \mathrm{~nm}$ that is assigned to the isoquinoline chromophore. The only exception is dye $\mathbf{1 8}$ where this peak is hidden under a strong absorption band corresponding to the pyrenyl moiety.

Most interesting are the fluorescence properties of the dyes (see spectra in Figure 2), which revealed a dual emission phenomenon (see ratio $I_{\mathrm{LW}} / I_{\mathrm{SW}}$ of the intensities $I$ of the long-wavelength (LW) and short-wavelength (SW) emission band; Table 1). The monitoring of the emission corresponding to both bands yields identical excitation spectra which also coincide with the absorption spectra of the dyes. This underpins the authenticity of the emission signals. The appearance of the LW emission for all investigated dyes can be clearly linked to the presence of the boron-containing substituent. This follows from the observation that the corresponding arylisoquinolines without boron substitution feature only one blue-shifted emission band that is very similar to the SW band of the borylated dye, e.g., the non-borylated analogues of the dyes $17, \mathbf{1 8}$, and 19 fea- 
Table 1: UV-vis and fluorescence properties of the dyes $16-19$ in various solvents.

\begin{tabular}{|c|c|c|c|c|c|}
\hline & $\begin{array}{l}\lambda_{\text {abs,max }}(\mathrm{nm}) \\
{\left[\varepsilon\left(\mathrm{M}^{-1} \mathrm{~cm}^{-1}\right)\right]}\end{array}$ & $\begin{array}{l}\lambda_{\text {fluo,max }}(\mathrm{nm}) \\
\text { SW/LW }\end{array}$ & $I_{\mathrm{LW}} / I_{\mathrm{SW}}$ & $\Phi_{\text {fluo }}$ & $\begin{array}{l}\text { Tfluo (ns) } \\
\text { SW/LW }\end{array}$ \\
\hline \multicolumn{6}{|c|}{$\mathrm{CH}_{2} \mathrm{Cl}_{2}$} \\
\hline 16 & 303 [10800] & $429 / 555$ & 7.1 & 0.59 & $0.43 / 6.11$ \\
\hline 17 & $296[11500]$ & $397 / 512$ & 7.1 & 0.17 & $0.16 / 3.96$ \\
\hline 18 & 345 [36900] & $431 / 549$ & 4.6 & 0.48 & $0.91 / 4.02$ \\
\hline 19 & $365[6900]$ & $409 / 551$ & 2.3 & 0.30 & $0.57 / 5.22$ \\
\hline \multicolumn{6}{|c|}{$\mathrm{CH}_{3} \mathrm{CN}$ (0.4 vol \% DMF as co-solvent) } \\
\hline 16 & 302 [10100] & $437 / 565$ & 15.7 & 0.48 & $0.40 / 6.03$ \\
\hline 17 & $294[16000]$ & $400 / 514$ & 11.2 & 0.14 & $0.13 / 3.26$ \\
\hline 18 & $343[33000]$ & $435 / 565$ & 3.0 & 0.35 & $0.39 / 4.74$ \\
\hline 19 & $363[13300]$ & $408 / 582$ & 2.4 & 0.15 & $0.32 / 4.83$ \\
\hline \multicolumn{6}{|c|}{$\left(\mathrm{CH}_{3}\right)_{2} \mathrm{SO}$} \\
\hline 16 & 304 [10500] & $451 / 577$ & 3.7 & 0.41 & $0.72 / 4.91$ \\
\hline 17 & $296[17400]$ & $402 / 519$ & 5.3 & 0.20 & $0.22 / 3.63$ \\
\hline 18 & 346 [29700] & $444 / 569$ & 1.8 & 0.47 & $0.55 / 4.81$ \\
\hline 19 & 366 [6500] & $413 / 592$ & 1.0 & 0.22 & $0.60 / 4.70$ \\
\hline
\end{tabular}
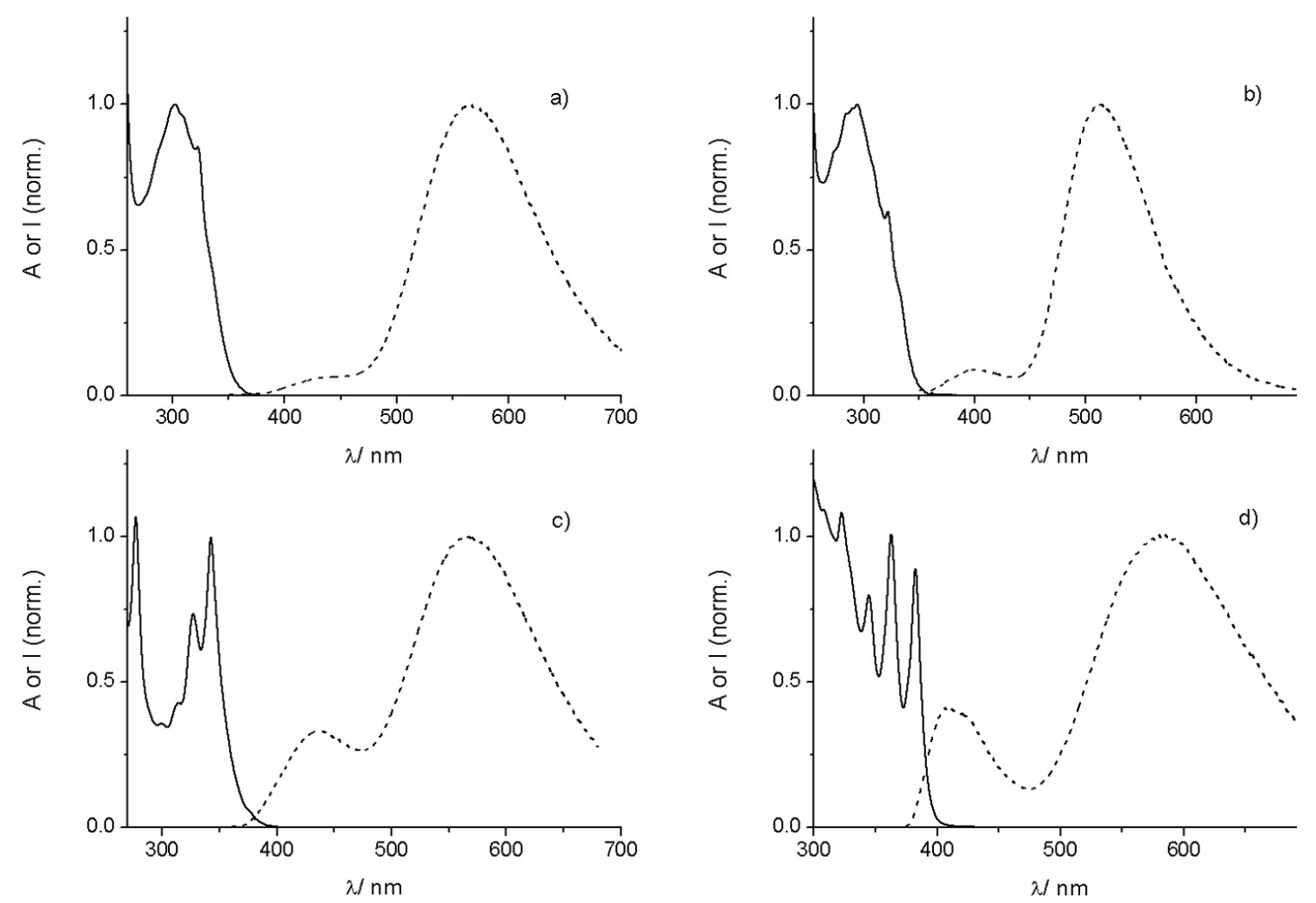

Figure 2: UV-vis absorption (solid line) and fluorescence (dashed line) spectra of a) 16, b) 17, c) 18, and d) 19 in air-equilibrated acetonitrile (containing $0.4 \mathrm{vol} \%$ DMF as co-solvent). 
ture a single emission band with a maximum at 401, 442, and $420 \mathrm{~nm}$, in acetonitrile, respectively. These are tentatively assigned to $\pi-\pi^{*}$ transitions of the variable aryl moiety. Interestingly, in tetrahydrofuran, containing oxygen as donor atom, only the SW emission band is seen, i.e., $\lambda_{\text {fluo,max }}=409 \mathrm{~nm}$ (16), $402 \mathrm{~nm} \mathrm{(17),} 426 \mathrm{~nm}(\mathbf{1 8}), 425 \mathrm{~nm}$ (19). This points to the interpretation that the SW emission has its origin in a Lewis adduct between the boron center as acceptor and the solvent as donor. The maxima of the rather broad LW bands of the dyes are observed between 510 and $590 \mathrm{~nm}$ in acetonitrile, corresponding to maximal apparent Stokes shifts of ca. 190-270 nm. As demonstrated previously for other borylated arylisoquinoline dyes $[37,38]$, the emission energy of the LW band is tightly linked with the redox potential of the aryl residue. Having in mind that the borylated naphthyl is present in all four dyes it is instructive to compare the oxidation potentials $\left(E_{\mathrm{ox}}\right)$ of the additional aryl residues. This leads to the following order: naphthyl $\left(E_{\mathrm{ox}}=1.70 \mathrm{~V}\right.$ vs SCE in acetonitrile $)>4$-methoxynaphthyl $(1.38 \mathrm{~V})>$ pyrenyl $(1.16 \mathrm{~V})>\operatorname{anthryl}(1.09 \mathrm{~V})$ [44]. On the one hand, the dye with the easiest oxidizable aromatic residue (dye 19) has the most red-shifted emission maximum, being at $582 \mathrm{~nm}$ in acetonitrile. On the other hand, dye 17 with a naphthyl, that is harder to oxidize, shows the most blue-shifted LW emission (maximum at $514 \mathrm{~nm}$ in acetonitrile). The LW emission maxima of other dyes (16 and 18) are situated in between. These trends support that for the herein investigated dyes intramolecular charge-transfer (ICT) phenomena might play a role in the observation of the LW emission features. According to our previous observations the electron-acceptor moiety is likely constituted by the isoquinolinyl moiety [37,38], while the donor is related to the electronically variable aryl residue. Comparing the emission maxima of the dyes in the less polar dichloromethane with those in the highly polar dimethyl sulfoxide, additional trends can be seen. Thus, dye $\mathbf{1 7}$ shows only a slight bathochromic shift of the emission maximum on changing to the polar solvent $(\Delta \lambda=+7 \mathrm{~nm})$. However, dye 19 features a solvatofluorochromic effect of $\Delta \lambda=+41 \mathrm{~nm}$ under the same conditions. The dyes $\mathbf{1 6}$ and $\mathbf{1 8}$ show somewhat smaller bathochromic shifts on increasing the solvent polarity $(\Delta \lambda=$ $+20-22 \mathrm{~nm}$ ).

Regarding the fluorescence quantum yields $\left(\Phi_{\text {fluo }}\right)$ of the dyes, the highest values were determined for the compounds $\mathbf{1 6}$ and 18, being in the range of $0.35-0.59$ in the investigated solvents. The dyes 17 and 19 show smaller values for $\Phi_{\text {fluo }}$ (ca. 0.15-0.30). The fluorescence lifetime of the SW emission was measured as 300-900 ps, being in some cases very close to the resolution limit of our time-correlated single-photon-counting setup. The LW emission showed considerably longer lifetimes in the 3-6 ns range. The photophysical behavior of the dyes is tentatively summarized in Scheme 4.

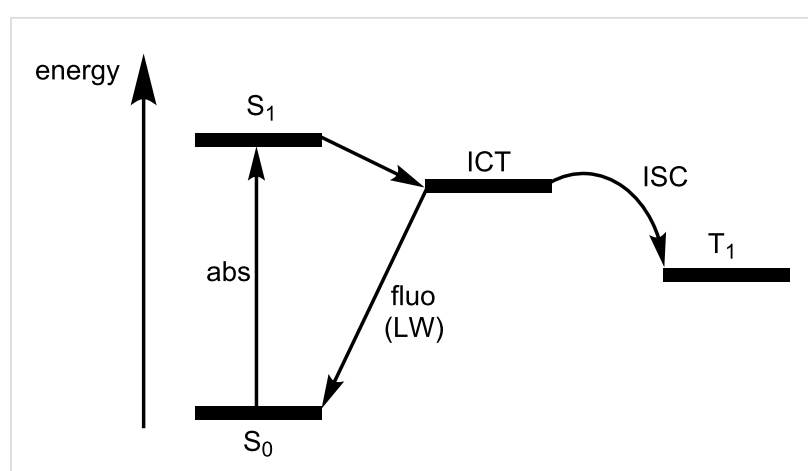

Scheme 4: Jablonski diagram representing the photophysical processes in the dyes 16-19.

\section{Laser-flash photolysis}

The photophysical characterization of the dyes 16-19 was completed by nanosecond laser-flash photolysis experiments in acetonitrile [45]. The laser excitation $\left(\lambda_{\text {exc }}=308 \mathrm{~nm}\right)$ of the dyes 16 and 17 in nitrogen-purged solution yielded transient absorption spectra with a broad band at $\lambda_{\max }=610$ and $600 \mathrm{~nm}$, respectively (see Figure 3 for dye 17). These transients showed lifetimes in the microsecond range $\left(\tau_{\mathrm{T}}=4.2 \mu \mathrm{s}(\mathbf{1 6})\right.$ and $4.4 \mu \mathrm{s}$ (17)), were efficiently quenched by oxygen (bimolecular quenching constant $k_{\mathrm{q}}$ ca. $1.1-1.2 \times 10^{9} \mathrm{M}^{-1} \mathrm{~s}^{-1}$ ), and led to the energy-transfer triplet-sensitization of $\beta$-carotene (observation of the triplet-triplet absorption band at $520 \mathrm{~nm}$ ). The experimental results corroborate the assignment of the transients to excited triplet states of $\mathbf{1 6}$ and $\mathbf{1 7}$. Noteworthy, the dyes $\mathbf{1 8}$ and 19 are characterized by distinct transient absorption spectra (excitation at $\lambda_{\mathrm{exc}}=355 \mathrm{~nm}$ ) with signals at shorter wavelengths. Based on the microsecond lifetime $\left(\tau_{\mathrm{T}}=3.1 \mu \mathrm{s}(\mathbf{1 8})\right.$ and $2.4 \mu \mathrm{s}$ (19)), oxygen quenching $\left(k_{\mathrm{q}}\right.$ ca. 2.9-3.1 $\left.\times 10^{9} \mathrm{M}^{-1} \mathrm{~s}^{-1}\right)$, and

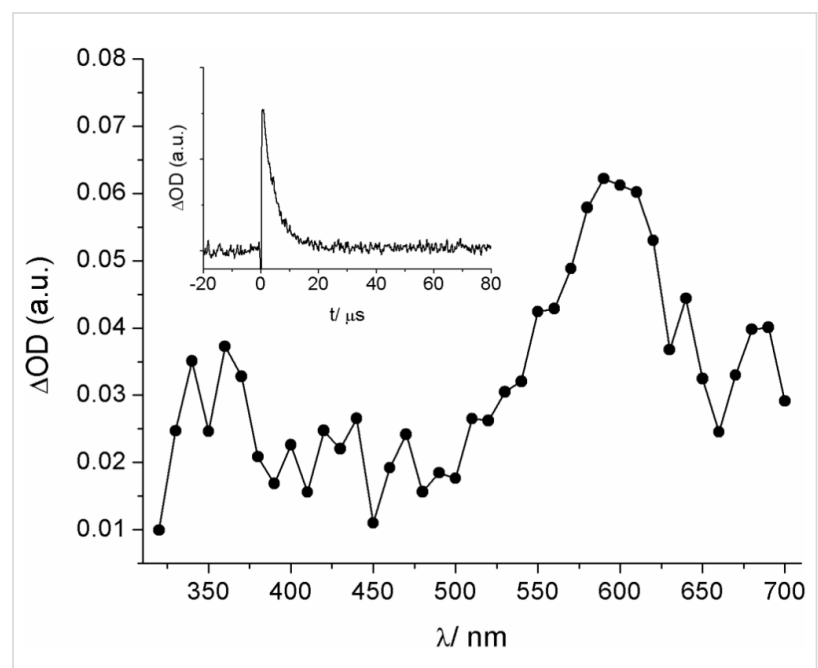

Figure 3: Transient absorption spectrum (600 ns delay) of dye 17 in nitrogen-purged acetonitrile on excitation at $308 \mathrm{~nm}$. The inset shows the corresponding kinetics at $600 \mathrm{~nm}$. 
$\beta$-carotene triplet sensitization experiments the signals at $410 \mathrm{~nm}$ (dye 18) and $430 \mathrm{~nm}$ (dye 19) were assigned to excited triplet states as well. An additional signal at $470 \mathrm{~nm}$ for dye $\mathbf{1 8}$ is insensitive to oxygen and was tentatively attributed to the formation of a pyrene-based radical cation, resulting from photoionization [46].

\section{Interaction with fluoride anions}

The presence of the boronic acid ester moiety does not only contribute to significant changes in the fluorescence properties but constitutes also a potential binding motif for Lewis bases. In this context it is well established that the electron-deficient trivalent boron can bind anions, such as fluoride or cyanide, through interaction with the vacant $2 \mathrm{p}_{\pi}$ orbital [30]. In Figure 4 the fluorescence responses of the dyes 16-19 on the addition of tetra- $n$-butylammonium fluoride $\left(\mathrm{Bu}_{4} \mathrm{NF}\right)$ in acetonitrile are depicted. The dyes $\mathbf{1 6}$ and $\mathbf{1 7}$ show a strong fluorescence quenching of their LW bands, while the SW bands experience a slight increase. However, the situation for the dyes $\mathbf{1 8}$ and $\mathbf{1 9}$ is dramatically different. Here the LW band is substituted by a strong blue-shifted emission. This leads to a clear ratiometric behavior and a large dynamic response. The blue-shifted emission for the fluoroboronate Lewis adduct is in accordance with the observations made for donor solvents such as tetrahydrofuran (see above). As for the dyes $\mathbf{1 6}$ and 17, also for $\mathbf{1 8}$ and 19 isoemissive points were noted. These observations corroborate the uniformity of the reaction with fluoride anions. The UV-vis absorption spectra show much smaller changes as compared to the fluorescence (not shown). However, also here isosbestic points were observed. The formation of the fluoroboronate complexes was corroborated by the detection of the corresponding mass peaks (see Supporting Information File 1). In addition, ${ }^{11}$ B NMR spectra, for the example of dye 17 , reveal that the boron changes from $\mathrm{sp}^{2}$ to $\mathrm{sp}^{3}$ hybridization on addition of 1 equiv $\mathrm{F}^{-}$; i.e., the ${ }^{11} \mathrm{~B}$ NMR signal shifts from $31.5 \mathrm{ppm}$ to $7.0 \mathrm{ppm}$ (see Supporting Information File 1). This is in line with the formation of the fluoroboronate complex, instead of unwanted processes such as protodeboronation which could be potentially caused by acid traces in $\mathrm{Bu}_{4} \mathrm{NF}$. Noteworthy, the addition of other anions, such as bromide, iodide, or cyanide did not result in significant changes of the optical spectra of the dyes.
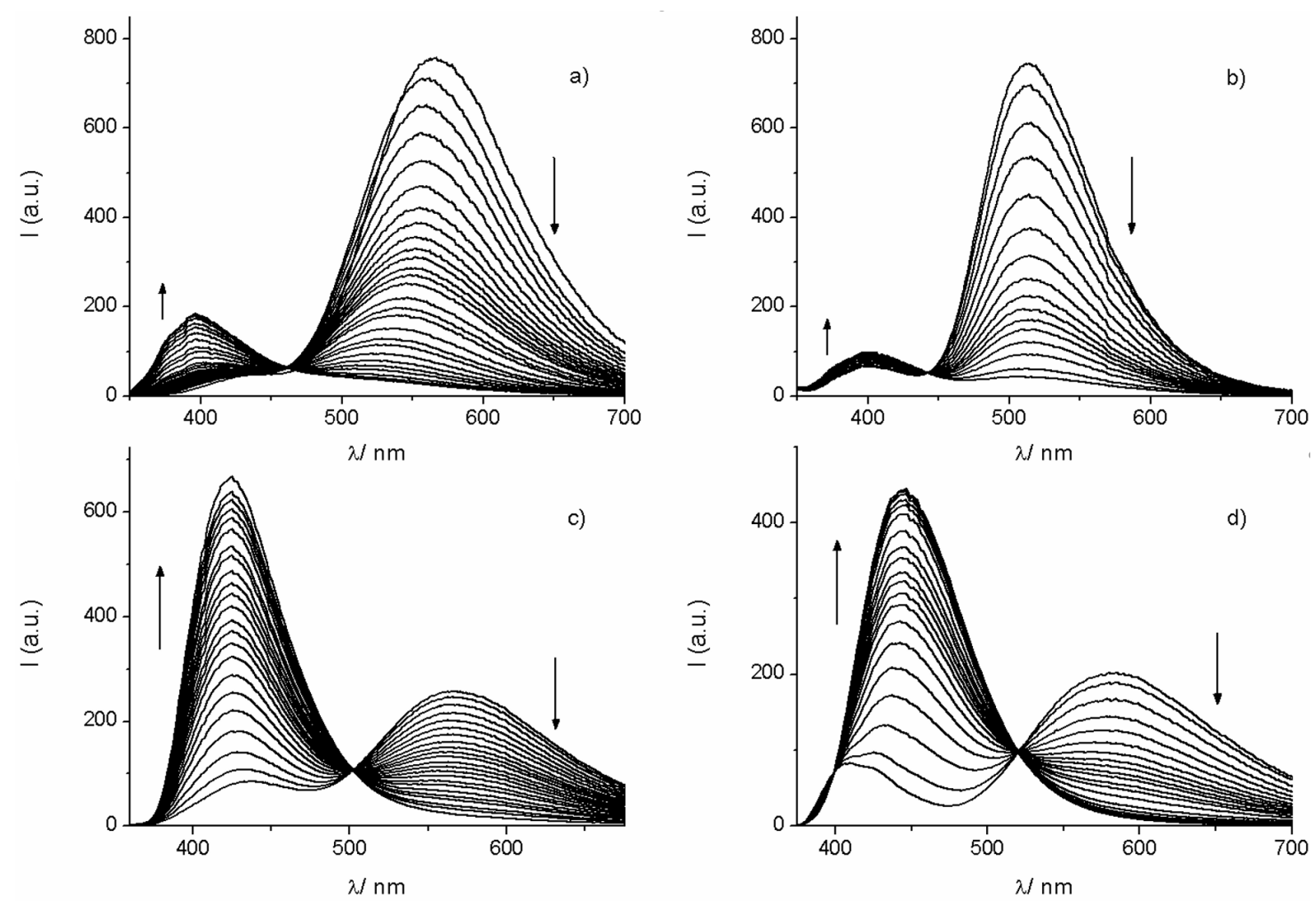

Figure 4: Fluorescence titrations of the dyes (ca. 4-11 $\mu \mathrm{M}$ ) with $\mathrm{Bu}_{4} \mathrm{NF}$ in acetonitrile. a) $\mathbf{1 6}$ (up to 156 equiv $\mathrm{F}^{-}$), b) $\mathbf{1 7}$ (up to 40 equiv $\mathrm{F}^{-}$), c) $\mathbf{1 8}$ (up to 152 equiv $\mathrm{F}^{-}$), d) 19 (up to 100 equiv $\mathrm{F}^{-}$). 
Fluorescence titrations yielded the formation constants for the respective 1:1 fluoroboronate complexes. The values are in the order of $10^{4} \mathrm{M}^{-1}\left(1.6 \times 10^{4} \mathrm{M}^{-1}(\mathbf{1 6}) ; 4.8 \times 10^{4} \mathrm{M}^{-1}\right.$ (17); $\left.2.6 \times 10^{4} \mathrm{M}^{-1}(\mathbf{1 8}) ; 2.0 \times 10^{4} \mathrm{M}^{-1}(\mathbf{1 9})\right)$, which are very comparable to the constants that were obtained for related borylated arylisoquinoline dyes [37].

\section{Conclusion}

The family of borylated arylisoquinoline dyes was extended by members that contain additional aryl substituents, leading to compounds with two stereogenic axes. The dyes show pronounced dual emission patterns with long-wavelength maxima close to $600 \mathrm{~nm}$ in polar solvents such as acetonitrile or dimethyl sulfoxide. The emission maxima of the long-wavelength band vary systematically with the electron-donor strength of the additional aryl residue (naphthyl, 4-methoxynaphthyl, pyrenyl, anthryl). This provides some hint that intramolecular charge-transfer phenomena are likely involved. Laser-flash photolysis studies provided insights into the existence of excited triplet states. The addition of fluoride anions led to pronounced fluorescence quenching effects, as the result of the formation of fluoroboronate complexes. In the case of the pyrenyl- and anthryl-substituted dyes a clear ratiometric behavior was noted. No quenching was seen for the addition of cyanide ions or bromide and chloride. This makes the new dyes selective fluorescent receptors for fluoride anions.

\section{Experimental}

\section{General methods and materials}

${ }^{1} \mathrm{H}$ NMR spectra were recorded at $400 \mathrm{MHz}$ or $500 \mathrm{MHz}$ and ${ }^{13} \mathrm{C}$ NMR spectra were recorded at $100 \mathrm{MHz}$ or $125 \mathrm{MHz}$. Chloroform- $d\left(\mathrm{CDCl}_{3}\right)$, acetone- $d_{6}\left(\left(\mathrm{CD}_{3}\right)_{2} \mathrm{CO}\right)$ and benzene- $d_{6}$ $\left(\mathrm{C}_{6} \mathrm{D}_{6}\right)$ were used as solvents and the solvent peak was employed as reference. ${ }^{11} \mathrm{~B}$ NMR spectra were recorded with complete proton decoupling at $160 \mathrm{MHz}$, using $\mathrm{BF}_{3} \cdot \mathrm{Et}_{2} \mathrm{O}(0.00 \mathrm{ppm}$ for ${ }^{11} \mathrm{~B}$ NMR) as standard.

All chemical reactions were carried out in oven-dried Schlenk tubes under an argon atmosphere. Toluene, 1,4-dioxane, and methanol were purchased from Carlo Erba and were used as received. Anhydrous THF was obtained using Grubbs-type solvent drying columns. $\left[\mathrm{Pd}\left(\mathrm{PPh}_{3}\right)_{4}\right], \mathrm{Pd}_{2}(\mathrm{dba})_{3}$, SPhos ligand, 1-chloroisoquinoline, and pinacolborane (HBpin) were supplied by Aldrich, $[\operatorname{Ir}(\mu-\mathrm{OMe})(\mathrm{cod})]_{2}$ was from Strem Chemicals, and bis(pinacolate)diboron $\left(\mathrm{B}_{2} \mathrm{pin}_{2}\right)$ was purchased from Frontier Scientific. All reagents were used as received. 1-Bromo-4methoxynaphthalene (1) [47], 1-chloroanthracene (4) [48], and 1-(tetrahydropyran-2'-yloxy)-4-bromonaphthalene (6) [49] were synthesized according to literature procedures. The solvents for the photophysical measurements were purchased from
Aldrich (acetonitrile) or Scharlau (dichloromethane, dimethyl sulfoxide) and were of spectroscopic quality.

UV-vis absorption and corrected fluorescence spectra were measured with standard equipment (Shimadzu UV-1603 and Varian Cary Eclipse), using quartz cuvettes of $1 \mathrm{~cm}$ optical path length. The fluorescence quantum yields were determined with quinine sulfate as standard reference $\left(\Phi_{\text {fluo }}=0.55\right.$ in $0.05 \mathrm{M}$ $\mathrm{H}_{2} \mathrm{SO}_{4}$ ) [50,51]. The lifetimes were measured by time-correlated single-photon counting (Edinburgh instruments FLS 920).

Laser-flash photolysis experiments were performed using a $\mathrm{XeCl}$ excimer laser $\left(\lambda_{\text {exc }}=308 \mathrm{~nm} ; 17 \mathrm{~ns}\right.$ fwhm; $20 \mathrm{~mJ} /$ pulse $)$. Alternatively, a Q-switched Nd:YAG laser (Quantel Brilliant, $355 \mathrm{~nm}, 5 \mathrm{~ns}$ fwhm, $15 \mathrm{~mJ} /$ pulse) was coupled to a mLFP-111 Luzchem miniaturized equipment. The concentration of 16-19 was kept in the range of $20-30 \mu \mathrm{M}$ in acetonitrile. The solutions were air-equilibrated or bubbled for 30 min with $\mathrm{N}_{2}$ or $\mathrm{O}_{2}$ before acquisition. All the experiments were carried out at room temperature.

The detailed procedures for the synthesis of the precursors can be found in Supporting Information File 1. Below the borylation of the precursors $\mathbf{1 2 - 1 5}$ to yield the dyes $\mathbf{1 6 - 1 9}$ is described and the NMR characterization data of the dyes are given.

\section{General procedure for the Ir-catalyzed bory- lation - synthesis of the dyes 16-19}

Following the described procedure [42], a dried Schlenk tube was loaded with the substrate (12-15) and $\mathrm{B}_{2} \mathrm{Pin}_{2}$ (1 equiv). After three vacuum-argon cycles, $1 \mathrm{~mL}$ catalyst stock solution per $0.5 \mathrm{mmol}$ substrate and pinacolborane (HBPin, $5 \mathrm{~mol} \%$ ) was added. The reaction mixture was stirred at $55{ }^{\circ} \mathrm{C}$ until quantitative consumption of the starting material. The mixture was cooled to room temperature, concentrated to dryness, and the crude product was purified by column chromatography (n-hexane/EtOAc mixtures).

Note: The catalyst stock solution $(25 \mathrm{~mL})$ was prepared by dissolving 2-pyridinecarboxaldehyde $N, N$-dibenzylhydrazone $(37.6 \mathrm{mg}, 0.125 \mathrm{mmol})$ and $[\operatorname{Ir}(\mu-\mathrm{OMe})(\operatorname{cod})]_{2}(41 \mathrm{mg}$, $0.063 \mathrm{mmol}$ ) in dry THF. Sonication for one hour was used to facilitate dissolution. The resulting red-brown solution was kept under argon.

1-(4'-Methoxy-3-(4,4,5,5-tetramethyl-1,3,2-dioxaborolan-2-yl)-[1,1'-binaphthalen]-4-yl)isoquinoline (16)

Following the above described general procedure for the Ir-catalyzed borylation starting from $12(85 \mathrm{mg}, 0.21 \mathrm{mmol})$ and after 
flash chromatography on silica gel (toluene/EtOAc 7:1), 16 was obtained as a light-yellow foam (70 mg, 62\% yield). NMR spectra recorded at $25{ }^{\circ} \mathrm{C}$ showed a ca. 0.45:0.55 diastereomeric mixture of atropisomers. To simplify the spectra the measurements were undertaken at $80{ }^{\circ} \mathrm{C} .{ }^{1} \mathrm{H}$ NMR $(400 \mathrm{MHz}$, $\left.\mathrm{C}_{6} \mathrm{D}_{6}, 80^{\circ} \mathrm{C}\right) \delta 8.80(\mathrm{~d}, J=5.6 \mathrm{~Hz}, 0.5 \mathrm{H}), 8.78(\mathrm{~d}, J=5.6 \mathrm{~Hz}$, $0.5 \mathrm{H}), 8.60(\mathrm{~d}, J=8.0 \mathrm{~Hz}, 0.5 \mathrm{H}), 8.58(\mathrm{~d}, J=8.0 \mathrm{~Hz}, 0.5 \mathrm{H})$, $8.46(\mathrm{~s}, 0.5 \mathrm{H}), 8.44(\mathrm{~s}, 0.5 \mathrm{H}), 7.70-7.47(\mathrm{~m}, 5 \mathrm{H}), 7.34-7.26(\mathrm{~m}$, 2H), 7.10-6.99 (m, 4H), $6.62(\mathrm{~d}, J=7.2 \mathrm{~Hz}, 0.5 \mathrm{H}), 6.61(\mathrm{~d}, J=$ $7.6 \mathrm{~Hz}, 0.5 \mathrm{H}), 3.61(\mathrm{~s}, 3 \mathrm{H}), 0.80(\mathrm{~s}, 6 \mathrm{H}), 0.69(\mathrm{~s}, 3 \mathrm{H}), 0.65(\mathrm{~s}$, $3 \mathrm{H}) \mathrm{ppm}$, two proton signals were hidden under the $\mathrm{C}_{6} \mathrm{D}_{6}$ peak; ${ }^{13} \mathrm{C}$ NMR $\left(100 \mathrm{MHz}, \mathrm{C}_{6} \mathrm{D}_{6}, 80{ }^{\circ} \mathrm{C}\right) \delta 162.8,156.1,145.7$, 145.6, 143.1, 138.9, 136.6, 135.5, 134.9 (br s), 133.5, 133.4, $131.9,130.6,129.5,128.6,127.4,127.1,126.8,126.6,126.2$, $125.5,125.4,122.8,122.5,120.1,119.7,119.6,104.4,104.1$, 83.4, 55.4, $24.6 \mathrm{ppm}, C-\mathrm{B}$ not observed; ${ }^{11} \mathrm{~B}$ NMR (128 MHz, $\mathrm{C}_{6} \mathrm{D}_{6}$ ) $\delta 32.0 \mathrm{ppm}$ (br s); HRESIMS m/z: $[\mathrm{M}+\mathrm{Na}]^{+}$calcd. for $\mathrm{C}_{36} \mathrm{H}_{32} \mathrm{BNNaO}_{3}$, 560.2367; found, 560.2370.

\section{1-(3-(4,4,5,5-Tetramethyl-1,3,2-dioxaborolan-2-yl)-} [1,1'-binaphthalen]-4-yl)isoquinoline (17)

Following the above described general procedure for the Ir-catalyzed borylation starting from $\mathbf{1 3}$ (95 mg, $0.25 \mathrm{mmol}$ ) and after flash chromatography on silica gel ( $n$-hexane/EtOAc 4:1), 17 was obtained as light-yellow foam (105 mg, 83\% yield). NMR spectra recorded at $25{ }^{\circ} \mathrm{C}$ showed a ca. 0.45:0.55 diastereomeric mixture of atropisomers. To simplify the spectra the measurements were undertaken at $80{ }^{\circ} \mathrm{C} .{ }^{1} \mathrm{H}$ NMR $(500 \mathrm{MHz}$, $\left.\mathrm{C}_{6} \mathrm{D}_{6}, 80^{\circ} \mathrm{C}\right) \delta 8.77($ br s, $1 \mathrm{H}), 8.38(\mathrm{~s}, 0.55 \mathrm{H}) 8.36(\mathrm{~s}, 0.45 \mathrm{H})$, $7.81-7.77(\mathrm{~m}, 3 \mathrm{H}), 7.68-7.53(\mathrm{~m}, 4.55 \mathrm{H}), 7.49$ (d, $J=5.5 \mathrm{~Hz}$, $1 \mathrm{H}), 7.39$ (br s, $1.45 \mathrm{H}), 7.30$ (br s, $1 \mathrm{H}), 7.25$ (br s, $1 \mathrm{H})$, 7.11-7.02 (m, 4H), 0.81 (s, 6H), $0.70(\mathrm{~s}, 3 \mathrm{H}), 0.68$ (s, 3H) ppm; ${ }^{13} \mathrm{C}$ NMR (100 MHz, $\left.\mathrm{C}_{6} \mathrm{D}_{6}, 80{ }^{\circ} \mathrm{C}\right) \delta 162.6,145.7,143.0$, 139.5, 138.6, 136.5, 135.0, 134.4, 133.9, 133.3, 133.0, 130.5, $129.5,128.7,128.5,127.9,127.5,127.1,127.1,126.7,126.6$, 126.3, 126.2, 126.1, 126.0, 125.8, 125.5, 119.6, 83.4, $24.5 \mathrm{ppm}$, $C$-B not observed; ${ }^{11} \mathrm{~B}$ NMR $\left(128 \mathrm{MHz}, \mathrm{C}_{6} \mathrm{D}_{6}\right) \delta 31.3 \mathrm{ppm}(\mathrm{br}$ s); HREIMS $\mathrm{m} / \mathrm{z}$ : $[\mathrm{M}]^{+}$calcd. for $\mathrm{C}_{35} \mathrm{H}_{30} \mathrm{BNO}_{2}, 507.2370$; found, 507.2375 .

1-(4-(Pyren-1-yl)-2-(4,4,5,5-tetramethyl-1,3,2-dioxaborolan-2-yl)naphthalen-1-yl)isoquinoline (18)

Following the above described general procedure for the Ir-catalyzed borylation starting from $14(114 \mathrm{mg}, 0.25 \mathrm{mmol})$ and after flash chromatography on silica gel ( $n$-hexane/EtOAc 5:1), 18 was obtained as a light-yellow foam (74 mg, 51\% yield). NMR spectra recorded at $25{ }^{\circ} \mathrm{C}$ showed a ca. 0.45:0.55 diastereomeric mixture of atropisomers. To simplify the spectra the measurements were undertaken at $80{ }^{\circ} \mathrm{C} .{ }^{1} \mathrm{H}$ NMR $(500 \mathrm{MHz}$, $\left.\mathrm{C}_{6} \mathrm{D}_{6}, 80{ }^{\circ} \mathrm{C}\right) \delta 8.87(\mathrm{~d}, J=5.5 \mathrm{~Hz}, 0.55 \mathrm{H}), 8.85(\mathrm{~d}, J=5.5 \mathrm{~Hz}$, $0.55 \mathrm{H}), 8.62(\mathrm{~s}, 0.55 \mathrm{H}), 8.59(\mathrm{~s}, 0.45 \mathrm{H}), 8.12(\mathrm{~d}, J=7.6 \mathrm{~Hz}$,
$0.55 \mathrm{H}), 8.08(\mathrm{~d}, J=9.1 \mathrm{~Hz}, 0.45 \mathrm{H}), 8.01-7.98(\mathrm{~m}, 2 \mathrm{H})$, 7.94-7.93 (m, 2H), 7.91-7.82 (m, 2H), 7.80-7.71 (m, 3H), $7.68-7.58(\mathrm{~m}, 3 \mathrm{H}), 7.47(\mathrm{~d}, J=5.5 \mathrm{~Hz}, 1 \mathrm{H}), 7.26(\mathrm{~d}, J=8.1 \mathrm{~Hz}$, $0.45 \mathrm{H}), 7.29(\mathrm{~d}, J=8.3 \mathrm{~Hz}, 0.55 \mathrm{H}), 7.12(\mathrm{~d}, J=7.4 \mathrm{~Hz}, 0.55 \mathrm{H})$, $7.09(\mathrm{~d}, J=6.9 \mathrm{~Hz}, 0.45 \mathrm{H}), 7.06-7.00(\mathrm{~m}, 3 \mathrm{H}), 0.79(\mathrm{~s}, 6 \mathrm{H})$, $0.65(\mathrm{~s}, 2.7 \mathrm{H}), 0.62(\mathrm{~s}, 3.3 \mathrm{H}) \mathrm{ppm} ;{ }^{13} \mathrm{C} \mathrm{NMR}\left(100 \mathrm{MHz}, \mathrm{C}_{6} \mathrm{D}_{6}\right.$, $\left.80^{\circ} \mathrm{C}\right) \delta 162.7,145.9,143.3,139.0,136.8,136.8,136.6,135.3$, 133.7, 133.4, 132.2, 131.9, 131.9, 131.6, 130.7, 130.6, 129.6, $129.3,127.3,126.8,126.6,126.5,126.4,126.4,126.2$, $125.8-125.7,125.5-125.3,124.8,119.6,83.5,24.5 \mathrm{ppm}, C-\mathrm{B}$ not observed; ${ }^{11} \mathrm{~B}$ NMR (128 MHz, $\left.\mathrm{C}_{6} \mathrm{D}_{6}\right) \delta 32.0 \mathrm{ppm}$ (br s); HREIMS $[\mathrm{M}]^{+}$calcd. for $\mathrm{C}_{41} \mathrm{H}_{32} \mathrm{BNO}_{2}, 581.2526$; found, 581.2530 .

\section{1-(4-(Anthracen-1-yl)-2-(4,4,5,5-tetramethyl-1,3,2- dioxaborolan-2-yl)naphthalen-1-yl)isoquinoline \\ (19)}

Following the above described general procedure for the Ir-catalyzed borylation starting from $15(84 \mathrm{mg}, 0.21 \mathrm{mmol})$ and after flash chromatography on silica gel (toluene/EtOAc 20:1), 19 was obtained as a yellow foam (100 mg, 72\% yield). NMR spectra recorded at $25{ }^{\circ} \mathrm{C}$ showed a ca. 0.44:0.56 diastereomeric mixture of atropisomers. To simplify the spectra the measurements were undertaken at $80{ }^{\circ} \mathrm{C} .{ }^{1} \mathrm{H}$ NMR $(500 \mathrm{MHz}$, $\left.\mathrm{C}_{6} \mathrm{D}_{6}, 80^{\circ} \mathrm{C}\right) \delta 8.81(\mathrm{~d}, J=5.6 \mathrm{~Hz}, 0.55 \mathrm{H}), 8.79(\mathrm{~d}, J=5.6 \mathrm{~Hz}$, $0.45 \mathrm{H}) 8.54(\mathrm{~s}, 0.55 \mathrm{H}), 8.49(\mathrm{~s}, 0.45 \mathrm{H}), 8.44(\mathrm{~s}, 0.45 \mathrm{H}), 8.33(\mathrm{~s}$, $1 \mathrm{H}), 8.26(\mathrm{~s}, 0.55 \mathrm{H}), 8.00-7.93(\mathrm{~m}, 1.45 \mathrm{H}), 7.81(\mathrm{t}, J=8.6 \mathrm{~Hz}$, $1 \mathrm{H}), 7.71-7.59(\mathrm{~m}, 4 \mathrm{H}), 7.49(\mathrm{~d}, J=5.6 \mathrm{~Hz}, 1 \mathrm{H}), 7.41-7.27(\mathrm{~m}$, $3 \mathrm{H}), 7.19-7.10(\mathrm{~m}, 1.55 \mathrm{H}), 7.05-6.97(\mathrm{~m}, 4 \mathrm{H}), 0.80(\mathrm{~s}, 2.7 \mathrm{H})$, $0.79(\mathrm{~s}, 3.3 \mathrm{H}), 0.69(\mathrm{~s}, 2.7 \mathrm{H}), 0.64(\mathrm{~s}, 3.3 \mathrm{H}) \mathrm{ppm} ;{ }^{13} \mathrm{C} \mathrm{NMR}$ $\left(125 \mathrm{MHz}, \mathrm{C}_{6} \mathrm{D}_{6}, 80{ }^{\circ} \mathrm{C}\right) \delta 162.6,145.9,145.9,143.1,143.0$, 139.6, 139.4, 138.8, 136.5, 135.2, 135.1, 133.3, 133.2, 132.6, $132.5,132.5,132.4,132.3,132.2,130.5,130.4,129.5,129.5$, $129.3,129.2,128.6,128.5,128.5,128.3,128.1,127.9,127.5$, 127.3, 127.2, 127.2, 127.1, 126.9, 126.8, 126.8, 126.7, 126.7, $126.5,126.3,126.3,126.1,125.8,125.6,125.4,125.2,125.2$, 119.6, 83.4, 24.5, $24.4 \mathrm{ppm}, C-\mathrm{B}$ not observed; ${ }^{11} \mathrm{~B}$ NMR (160 MHz, $\mathrm{C}_{6} \mathrm{D}_{6}$ ) $\delta 31.5 \mathrm{ppm}$ (br s); HREIMS m/z: [M] ${ }^{+}$calcd. for $\mathrm{C}_{39} \mathrm{H}_{32} \mathrm{BNO}_{2}$, 557.2526; found, 557.2508.

\section{Supporting Information}

\section{Supporting Information File 1}

Additional synthetic procedures for $\mathbf{2 , 3}, \mathbf{5}$, and $\mathbf{7 - 1 5},{ }^{1} \mathrm{H}$ and ${ }^{13} \mathrm{C}$ NMR spectra of the dyes $\mathbf{1 6}-\mathbf{1 9}$ and their precursors, ESIMS spectra and ${ }^{11} \mathrm{~B}$ NMR spectroscopy of fluoroboronate complexes, HPLC traces for the dyes 16-19.

[https://www.beilstein-journals.org/bjoc/content/ supplementary/1860-5397-15-254-S1.pdf] 


\section{Acknowledgements}

Funding by the Spanish Ministry of Economy, Industry, and Competitiveness (CTQ2014-54729-C2-1-P for U.P., CTQ201348164-C2-1-P and CTQ2013-48164-C2-2-P for A.R., Ramón y Cajal contracts RYC-2013-12585 for A.R. and RYC-201517737 for I.V.), the Spanish Ministry of Science, Innovation, and Universities (CTQ2017-89832-P for U.P., CTQ201678875-P for M.C.J., and CTQ2017-89416-R for I.V.), the European Research and Development Fund, and the Andalusian Government (2012/FQM-2140 for U.P., 2009/FQM-4537 and 2012/FQM-1078 for A.R) is gratefully acknowledged.

\section{ORCID ${ }^{\circledR}$ iDs}

Ignacio Vayá - https://orcid.org/0000-0003-1682-9342 Abel Ros - https://orcid.org/0000-0002-3455-5675 Uwe Pischel - https://orcid.org/0000-0001-8893-9829

\section{References}

1. Frath, D.; Massue, J.; Ulrich, G.; Ziessel, R. Angew. Chem. 2014, 126, 2322-2342. doi:10.1002/ange.201305554 Angew. Chem., Int. Ed. 2014, 53, 2290-2310. doi:10.1002/anie.201305554

2. Ji, L.; Griesbeck, S.; Marder, T. B. Chem. Sci. 2017, 8, 846-863. doi:10.1039/c6sc04245g

3. Loudet, A.; Burgess, K. Chem. Rev. 2007, 107, 4891-4932. doi:10.1021/cr078381n

4. Ulrich, G.; Ziessel, R.; Harriman, A. Angew. Chem. 2008, 120, 1202-1219. doi:10.1002/ange.200702070

Angew. Chem., Int. Ed. 2008, 47, 1184-1201. doi:10.1002/anie.200702070

5. Amarne, H.; Baik, C.; Murphy, S. K.; Wang, S. Chem. - Eur. J. 2010, 16, 4750-4761. doi:10.1002/chem.200903582

6. Pais, V. F.; Alcaide, M. M.; López-Rodríguez, R.; Collado, D.; Nájera, F.; Pérez-Inestrosa, E.; Álvarez, E.; Lassaletta, J. M.; Fernández, R.; Ros, A.; Pischel, U. Chem. - Eur. J. 2015, 21 , 15369-15376. doi:10.1002/chem.201501626

7. Shaikh, A. C.; Ranade, D. S.; Thorat, S.; Maity, A.; Kulkarni, P. P.; Gonnade, R. G.; Munshi, P.; Patil, N. T. Chem. Commun. 2015, 51, 16115-16118. doi:10.1039/c5cc06351e

8. Liu, K.; Lalancette, R. A.; Jäkle, F. J. Am. Chem. Soc. 2017, 139, 18170-18173. doi:10.1021/jacs.7b11062

9. Vanga, M.; Lalancette, R. A.; Jäkle, F. Chem. - Eur. J. 2019, 25, 10133-10140. doi:10.1002/chem.201901231

10. Santos, F. M. F.; Rosa, J. N.; Candeias, N. R.; Parente Carvalho, C.; Matos, A. I.; Ventura, A. E.; Florindo, H. F.; Silva, L. C.; Pischel, U.; Gois, P. M. P. Chem. - Eur. J. 2016, 22, 1631-1637. doi:10.1002/chem.201503943

11. Alcaide, M. M.; Santos, F. M. F.; Pais, V. F.; Carvalho, J. I.; Collado, D.; Pérez-Inestrosa, E.; Arteaga, J. F.; Boscá, F.; Gois, P. M. P.; Pischel, U. J. Org. Chem. 2017, 82, 7151-7158. doi:10.1021/acs.joc.7b00601

12. Frath, D.; Azizi, S.; Ulrich, G.; Retailleau, P.; Ziessel, R. Org. Lett. 2011, 13, 3414-3417. doi:10.1021/0l2011665

13. Urban, M.; Durka, K.; Jankowski, P.; Serwatowski, J.; Luliński, S. J. Org. Chem. 2017, 82, 8234-8241. doi:10.1021/acs.joc.7b01001
14. Wakamiya, A.; Taniguchi, T.; Yamaguchi, S. Angew. Chem. 2006, 118, 3242-3245. doi:10.1002/ange.200504391

Angew. Chem., Int. Ed. 2006, 45, 3170-3173.

doi:10.1002/anie.200504391

15. Rao, Y.-L.; Wang, S. Inorg. Chem. 2011, 50, 12263-12274. doi:10.1021/ic200658v

16. Li, D.; Zhang, H.; Wang, Y. Chem. Soc. Rev. 2013, 42, 8416-8433. doi:10.1039/c3cs60170f

17. Coskun, A.; Akkaya, E. U. J. Am. Chem. Soc. 2006, 128, 14474-14475. doi:10.1021/ja066144g

18. Bozdemir, O. A.; Guliyev, R.; Buyukcakir, O.; Selcuk, S.; Kolemen, S.; Gulseren, G.; Nalbantoglu, T.; Boyaci, H.; Akkaya, E. U. J. Am. Chem. Soc. 2010, 132, 8029-8036. doi:10.1021/ja1008163

19. Niu, L.-Y.; Guan, Y.-S.; Chen, Y.-Z.; Wu, L.-Z.; Tung, C.-H.; Yang, Q.-Z. J. Am. Chem. Soc. 2012, 134, 18928-18931. doi:10.1021/ja309079f

20. Zhang, X.; Xiao, Y.; Qi, J.; Qu, J.; Kim, B.; Yue, X.; Belfield, K. D. J. Org. Chem. 2013, 78, 9153-9160. doi:10.1021/jo401379g

21. Zheng, Q.; Xu, G.; Prasad, P. N. Chem. - Eur. J. 2008, 14, 5812-5819. doi:10.1002/chem.200800309

22. Han, J.; Loudet, A.; Barhoumi, R.; Burghardt, R. C.; Burgess, K. J. Am. Chem. Soc. 2009, 131, 1642-1643. doi:10.1021/ja8073374

23. Kowada, T.; Maeda, H.; Kikuchi, K. Chem. Soc. Rev. 2015, 44 , 4953-4972. doi:10.1039/c5cs00030k

24. Kolemen, S.; Işık, M.; Kim, G. M.; Kim, D.; Geng, H.; Buyuktemiz, M.; Karatas, T.; Zhang, X.-F.; Dede, Y.; Yoon, J.; Akkaya, E. U. Angew. Chem. 2015, 127, 5430-5434. doi:10.1002/ange.201411962 Angew. Chem., Int. Ed. 2015, 54, 5340-5344. doi:10.1002/anie.201411962

25. Bachollet, S. P. J. T.; Volz, D.; Fiser, B.; Münch, S.; Rönicke, F.; Carrillo, J.; Adams, H.; Schepers, U.; Gómez-Bengoa, E.; Bräse, S.; Harrity, J. P. A. Chem. - Eur. J. 2016, 22, 12430-12438. doi:10.1002/chem.201601915

26. Frath, D.; Didier, P.; Mély, Y.; Massue, J.; Ulrich, G. ChemPhotoChem 2017, 1, 109-112. doi:10.1002/cptc.201700012

27. Kubo, Y.; Yamamoto, M.; Ikeda, M.; Takeuchi, M.; Shinkai, S.; Yamaguchi, S.; Tamao, K. Angew. Chem. 2003, 115, 2082-2086. doi:10.1002/ange.200250788

Angew. Chem., Int. Ed. 2003, 42, 2036-2040. doi:10.1002/anie.200250788

28. Melaimi, M.; Gabbaï, F. P. J. Am. Chem. Soc. 2005, 127, 9680-9681. doi:10.1021/ja053058s

29. Hudnall, T. W.; Kim, Y.-M.; Bebbington, M. W. P.; Bourissou, D.; Gabbaï, F. P. J. Am. Chem. Soc. 2008, 130, 10890-10891. doi:10.1021/ja804492y

30. Wade, C. R.; Broomsgrove, A. E. J.; Aldridge, S.; Gabbaï, F. P. Chem. Rev. 2010, 110, 3958-3984. doi:10.1021/cr900401a

31. Hudson, Z. M.; Liu, X.-Y.; Wang, S. Org. Lett. 2011, 13, 300-303. doi:10.1021/ol102749y

32. Bai, D.-R.; Liu, X.-Y.; Wang, S. Chem. - Eur. J. 2007, 13, 5713-5723. doi:10.1002/chem.200700364

33. Pron, A.; Zhou, G.; Norouzi-Arasi, H.; Baumgarten, M.; Müllen, K. Org. Lett. 2009, 11, 3550-3553. doi:10.1021/ol9012487

34. Pan, H.; Fu, G.-L.; Zhao, Y.-H.; Zhao, C.-H. Org. Lett. 2011, 13, 4830-4833. doi:10.1021/ol201909r

35. Bonn, A. G.; Wenger, O. S. J. Org. Chem. 2015, 80, 4097-4107. doi:10.1021/acs.joc.5b00416 
36. Griesbeck, S.; Zhang, Z.; Gutmann, M.; Lühmann, T.; Edkins, R. M.; Clermont, G.; Lazar, A. N.; Haehnel, M.; Edkins, K.; Eichhorn, A.; Blanchard-Desce, M.; Meinel, L.; Marder, T. B. Chem. - Eur. J. 2016, 22, 14701-14706. doi:10.1002/chem.201602639

37. Pais, V. F.; El-Sheshtawy, H. S.; Fernández, R.; Lassaletta, J. M.; Ros, A.; Pischel, U. Chem. - Eur. J. 2013, 19, 6650-6661. doi:10.1002/chem.201203887

38. Pais, V. F.; Lineros, M.; López-Rodríguez, R.; El-Sheshtawy, H. S.; Fernández, R.; Lassaletta, J. M.; Ros, A.; Pischel, U. J. Org. Chem. 2013, 78, 7949-7961. doi:10.1021/j0401147t

39. Pais, V. F.; Lassaletta, J. M.; Fernández, R.; El-Sheshtawy, H. S.; Ros, A.; Pischel, U. Chem. - Eur. J. 2014, 20, 7638-7645. doi:10.1002/chem.201402027

40. Domínguez, Z.; López-Rodríguez, R.; Álvarez, E.; Abbate, S.; Longhi, G.; Pischel, U.; Ros, A. Chem. - Eur. J. 2018, 24, 12660-12668. doi:10.1002/chem.201801908

41. Billingsley, K. L.; Barder, T. E.; Buchwald, S. L. Angew. Chem. 2007, 119, 5455-5459. doi:10.1002/ange.200701551 Angew. Chem., Int. Ed. 2007, 46, 5359-5363. doi:10.1002/anie.200701551

42. Ros, A.; Estepa, B.; López-Rodríguez, R.; Álvarez, E.; Fernández, R.; Lassaletta, J. M. Angew. Chem. 2011, 123, 11928-11932. doi:10.1002/ange.201104544 Angew. Chem., Int. Ed. 2011, 50, 11724-11728. doi:10.1002/anie.201104544

43. Zhu, L.; Shabbir, S. H.; Gray, M.; Lynch, V. M.; Sorey, S.; Anslyn, E. V. J. Am. Chem. Soc. 2006, 128, 1222-1232. doi:10.1021/ja055817c

44. Montalti, M.; Credi, A.; Prodi, L.; Gandolfi, M. T. Handbook of Photochemistry, 3rd ed.; Taylor \& Francis: Boca Raton, FL, 2006. doi:10.1201/9781420015195

45. Boscá, F.; Cuquerella, M. C.; Pais, V. F.; Ros, A.; Pischel, U. ChemPhotoChem 2018, 2, 34-41. doi:10.1002/cptc.201700176

46. Hara, M.; Tojo, S.; Kawai, K.; Majima, T. Phys. Chem. Chem. Phys. 2004, 6, 3215-3220. doi:10.1039/b403409k

47. Carreño, M. C.; García-Ruano, J. L.; Sanz, G.; Toledo, M. A.; Urbano, A. J. Org. Chem. 1995, 60, 5328-5331. doi:10.1021/j000121a064

48. Moursounidis, J.; Wege, D. Aust. J. Chem. 1988, 41, 235-249. doi:10.1071/ch9880235

49. Weimar, M.; Dürner, G.; Bats, J. W.; Göbel, M. W. J. Org. Chem. 2010, 75, 2718-2721. doi:10.1021/j0100053j

50. Melhuish, W. H. J. Phys. Chem. 1960, 64, 762-764. doi:10.1021/j100835a014

51. Melhuish, W. H. J. Phys. Chem. 1961, 65, 229-235. doi:10.1021/j100820a009

\section{License and Terms}

This is an Open Access article under the terms of the Creative Commons Attribution License (http://creativecommons.org/licenses/by/4.0). Please note that the reuse, redistribution and reproduction in particular requires that the authors and source are credited.

The license is subject to the Beilstein Journal of Organic Chemistry terms and conditions:

(https://www.beilstein-journals.org/bjoc)

The definitive version of this article is the electronic one which can be found at:

doi:10.3762/bjoc. 15.254 